\title{
PENINGKATAN LIFE SKILL PADA IBU-IBU LPKK DI DUSUN PAJANGAN BERBAH MELALUI PELATIHAN BROWNIES BEKATUL
}

\author{
Sri Wahyu Andayani', Rina Setyaningsih², Ika Wahyu Kusuma Wati3 , Roni \\ Kurniawan4 \\ Prodi Pendidikan Vokasional Kesejahteraan Keluarga,Universitas Sarjanawiyata \\ Tamansiswa, 1,2,3,4, Jl. Batikan Tuntungan UH III/1043 Umbulharjo \\ 1 E-mail address buswandayani@yahoo.com ; 2 E-mail address \\ rina.setyaningsih1202@gmail.com,3 E-mail address ika.wahyu@ustjogja.ac.id ; 4 E-mail \\ address ronnikur@gmail.com
}

\begin{abstract}
Increased life skills for mothers in Pajangan sub-village through rice bran training. The purpose of the training is to improve life skills in the Pajangan sub-village, especially in food products using local bran ingredients. Rice bran has a variety of nutrients including antioxidants containing tocopherol, vitamin $E$ and vitamin B15. These compounds play a role to reduce blood cholesterol levels, prevent cancer and facilitate hormonal secretions. Besides rice, rice husks or rice bran are not only sold to feed livestock, but are developed to make quality and quality products, but also can increase income and improve the living standards of LPKK women in Pajangan Berbah Hamlet, Sleman. The kinds of products we make are wet brownies and dry brownies. Abdimas is held in the Pajangan hamlet hall, Berbah Sleman. This activity was carried out for two days, namely the preparation phase on the first day and the implementation and socialization on the second day with a total of twelve hours of activity time. The target of this activity is LPKK women in the Pajangan Berbah Sleman. This activity is carried out using lecture, demonstration, training and practice methods. The resulting output is an increase in life skills through the skills to make bran brownies is a weekly newpepper.
\end{abstract}

Keywords: Life Skill, Training, Rice Bran

Abstrak
Peningkatan life skill pada ibu-ibu di dusun Pajangan melalui pelatihan
brownies bekatul. Tujuan pelatihan yaitu meningkatkan life skill di dusun
Pajangan terutama pada produk makanan dengan menggunakan bahan
lokal bekatul. Bekatul memiliki kandungan gizi yang beragam diantaranya
mengandung antioksidan tokoferol, vitamin E dan vitamin B15. Senyawa
tersebut berperan untuk menurunkan kadar kolestrol darah, mencegah
terjadinya kanker dan memperlancar sekresi hormonal. Selain beras, kulit
padi atau bekatul tidak hanya dijual untuk makan ternak, tetapi


dikembangkan untuk dibuat produk yang bermutu dan berkualitas, selain itu juga dapat menambah income dan meningkatkan taraf hidup ibu-ibu LPKK di Dusun Pajangan Berbah Sleman. Adapun macam produk yang kami buat yaitu brownis basah dan brownis kering. Abdimas dilaksanakan di Balai dusun Pajangan, Berbah Sleman. Kegiatan ini dilaksanakan selama dua hari yaitu tahap persiapan pada hari pertama dan pelaksanaan maupun sosialisasi pada hari kedua dengan total jam kegiatan sebesar dua belas jam. Sasaran kegiatan ini adalah ibu-ibu LPKK di dusun Pajangan Berbah. Kegiatan ini dilaksanakan dengan metode ceramah, demonstrasi, pelatihan dan praktek. Luaran yang dihasilkan peningkatan life skill melalui ketrampilan membuat brownies bekatul adalah surat kabar mingguan.

Kata Kunci: Life Skill, Pelatihan, Brownis Bekatul

\section{PENDAHULUAN}

Life skill merupakan kecakapan yang dimiliki oleh seseorang untuk menghadapi permasalahan dalam kehidupan dengan kreativitas dan inovatif. Life skill dapat ditingkatkan dengan melihat potensi warga disekitarnya, potensi warga tersebut tidak hanya dilihat pada keahlian individu saja, akan tetapi dari kekayaan alam di daerah tersebut, sehingga dapat meningkatkan life skill pada warga. Dengan demikian life skill merupakan salah satu cara untuk meningkatkan life skill pada ibu-ibu di dusun Pajangan dalam rangka meningkatkan taraf hidup keluarganya. Peningkatan ini tidak serta merta dapat dilakukan secara mandiri. Permasalahan tersebut dikarenakan kurangnya keterampilan dan keahlian, sehingga warga di dusun Pajangan perlu untuk diberdayakan. Hasil wawancara pada salah satu warga di dusun Pajangan diperoleh bahwa setiap warga di dusun Pajangan memiliki buah kulit padi/ bekatul yang kurang dimanfaatkan, selama ini bekatul hanya di gunakan sebagai makanan ternak. Padahal jika tingkat produksi yang tinggi dengan tidak diimbangi inovatif pada produk. Maka produk tersebut lama-kelamaan akan tidak laku. Salah satu upaya peningkatan tersebut perlu adanya pemberdayaan pada warganya.

Pemberdayaan atau pemberkuasaan (Empowerment) secara konseptual berasal dari kata 'power' (kekuasaan atau keberdayaan)[1]. Kekuasaan sering kali dianggap sebagai kemampuan seseorang untuk melakukan apa yang kita inginkan, sedangkan pemberdayaan dianggap sebagai kemampuan seseorang khususnya pada kelompok rentan dan lemah sehingga mereka memiliki kemampuan dan kekuatan yang ada di dalam diri mereka dapat memenuhi kebutuhan dasar 
sehari-hari sehingga mereka memiliki kebebasan. Pemberdayaan ini berfungsi untuk meningkatkan taraf hidup warga untuk menjadi lebih baik dari sebelumnya dan meningkatkan derajat kehidupan mereka yang lebih baik. Pelatihan ketrampilan bertujuan untuk memberikan keterampilan sebagai bekal dalam berwirausaha, mendorong munculnya kelompok-kelompok usaha baru, meningkatkan kualitas kehidupan perempuan, mendorong kemandirian keluarga terutama perempuan. Dengan adanya pemberdayaan ini masyarakat diharapkan untuk membangun kesadarannya, mendorong, memotivasi, dan membangkitkan kesadaran yang dimilikinya untuk berupaya mengembangkannya[2]. Bekatul memiliki kandungan gizi yang beragam diantaranya mengandung antioksidan tokoferol, vitamin E dan vitamin B15[3]. Senyawa tersebut berperan untuk menurunkan kadar kolestrol darah, mencegah terjadinya kanker dan memperlancar sekresi hormonal. Selain beras, kulit padi atau bekatul tidak hanya dijual untuk makan ternak, tetapi dikembangkan untuk dibuat produk yang bermutu dan berkualitas, selain itu juga dapat menambah income dan meningkatkan taraf hidup ibu-ibu LPKK di Dusun Pajangan Berbah Sleman. Dari pemaparan diatas diketahui bahwa perlu adanya peningkatan life skill. Peningkatan life skill dapat dilakukan dengan pemberdayaan warga melalui olahan yang inovatif pada pembuatan brownies bekatul

\section{METODE DAN PELAKSANAAN}

Bagian ini berisi metode pengabdian dan pelaksanaan kegiatan.

\section{Metode}

Kegiatan Abdimas ini dilaksanakan untuk meningkatkan life skill melalui pelatihan pembuatan brownies bekatul pada ibu-ibu LPKK di balai Dusun Pajangan Berbah. Pelatihan dilaksanakan dengan tiga instruktur yaitu tiga dosen dan satu pembantu pelaksana yaitu mahasiswa. Pelaksanaan kegiatan menggunakan tiga motode pelatihan dalam kegiatan pengabdian masyarakat untuk mendukung keberhasilan program pengabdian masyarakat antara lain: 1) Ceramah dan Tanya Jawab, metode ini dipilih untuk menjelaskan tentang materi yang bersifat teoritis terkait dengan definisi dari bekatul meliputi pengertian, fungsi, kandungan gizi, proses pembuatan tepung bekatul dan cara memilih, menangani dan menyimpan bekatul serta proses pengolahan menjadi brownis bekatul; 2)Demonstrasi, metode ini digunakan untuk menjelaskan suatu 
proses kerja secara bertahap, sehingga member kemudahan pada peserta pelatihan, peserta dapat mengamati secara cermat proses pembuatan brownis bekatul mulai dari tahap persiapan (mise en plase) meliputi: persiapan diri, alat dan bahan yang digunakan dalam pelatihan secara detail, sampai dengan proses pembuatan dan pengolahan brownis basah dan kering sampai dengan food plating dan tahap packaging; 3) Latihan/ Praktik/Tutorial pada metode ini peserta khususnya anggota LPKK mempraktikan proses pembuatan brownis basah dan kering sesuai dengan bimbingan dan arahan dari instruktur pelatihan, mulai dari membuat adonan, mengoven dan mengarnis sesuai dengan selera dari ibu-ibu LPKK. Dalam hal ini masyarakat sangat antusias dan tertarik, sehingga mereka berpartisipasi dalam setiap tahapan yang kami lakukan. Pelatihan ini dihadiri oleh 45 ibu-ibu di Dusun Pajangan, Minggiran Sendangtirto Berbah Sleman.

\section{Pelaksanaan Kegiatan}

Pelaksanaan kegiatan ini diadakan di LPKK di Dusun Pajangan, Minggiran Sendangtirto Berbah Sleman pada Sabtu, 27 Juli 2019, pelatihan ini dihadiri oleh 45 ibu-ibu yang mempunyai latar belakang sebagai ibu rumah tangga yang suaminya mempunyai ternak sapi, selain itu juga berasal dari petani, maupun buruh.

\section{HASIL DAN PEMBAHASAN}

Indikator keberhasilan kegiatan kepada masyarakat yaitu peningkatan life skill melalui pelatihan pembuatan brownies bekatul yaitu dapat: membuat brownies dari bekatul, meningkatkan income dan peningkatan taraf hidup masyarakat pajangan, menambah ketrampilan dan wawasan masyarakat. Hal tersebut didukung dengan hasil pelatihan yang dilakukan tentang pelatihan pemanfaatan dedak padi/ rice bran sebagai bahan tambahan pangan dan produk perawatan tubuh bagi masyarakat yang dapat meningkatkan kemandirian ekonomi dan kesejahteraan masyarakat[4]. Hal tersebut juga sejalan dengan pelatihan tentang pembuatan es krim yang dapat meningkatkan perekonomian masyarakat[5] dan bekatul merupakan makanan kaya serat yang sangat menyehatkan bagi tubuh[6]. Sebelum diolah menjadi brownis bekatul harus dilakukan penanganan terlebih dahulu dengan cara di oven, hal tersebut bertujuan menghindari ketengikan hidrolitik

Upaya stabilisasi dedak dan bekatul beras dapat dilakukan melalui inaktivasi enzim lipase dan lipoksigenase, antara 
lain dengan pengaturan $\mathrm{pH}$, pemanasan kering, pemanasan uap, penggunaan energi microwave, pemakaian uap etanol, hingga pemanfaatan antioksidan[7].

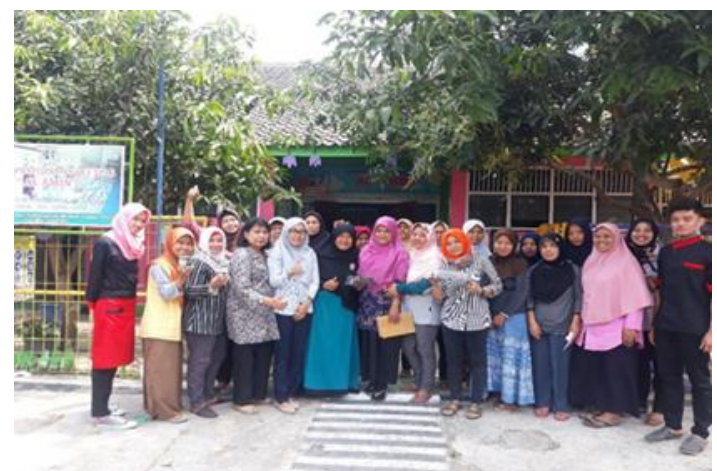

Gambar 1. TIM ABDIMAS dan peserta Pelatihan Brownis Bekatul

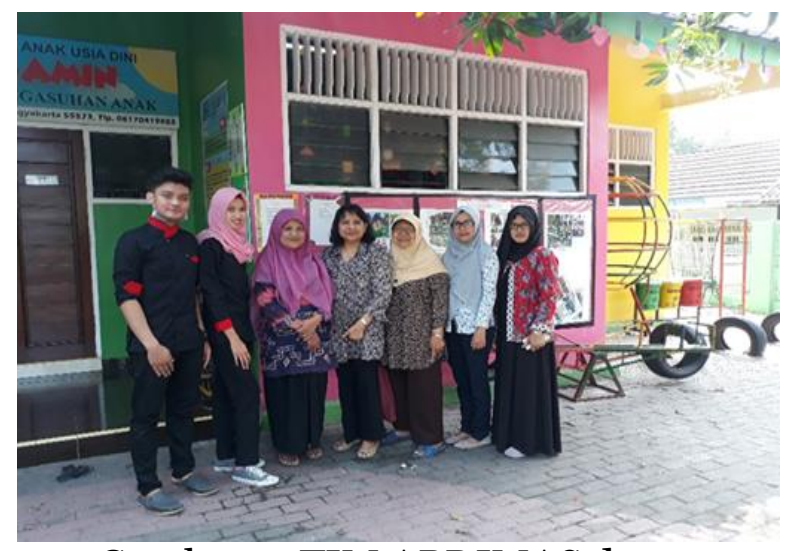

Gambar 2. TIM ABDIMAS dan Pengurus LPKK Dusun Pajangan

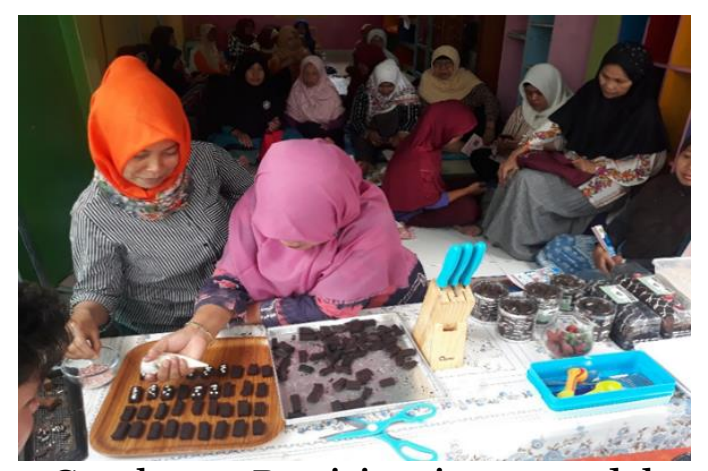

Gambar 3. Partisipasi peserta dalam pelatihan brownis bekatul
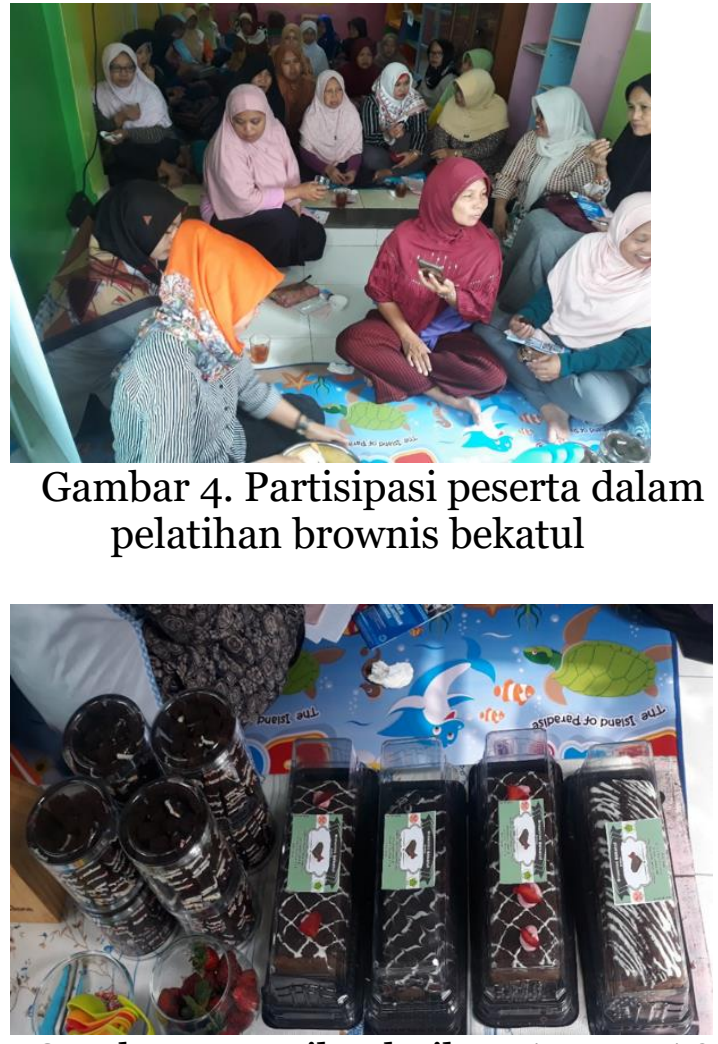

Gambar 5. Hasil Pelatihan ABDIMAS Brownis Bekatul

\section{PENUTUP}

Pelatihan peningkatan lifeskill pembuatan brownies bekatul dapat disimpulkan dan saran sebagai berikut.

\section{Simpulan}

Setelah dilaksanakan ABDIMAS dengan kegiatan Peningkatan life skill pada ibu-ibu di dusun Pajangan melalui pelatihan brownies bekatul bahwa peserta pelatihan, khususnya ibu-ibu LPKK di Dusun Pajangan, Minggiran Sendangtirto Berbah Sleman sangat antusias melaksanakan pelatihan, sehingga peserta bersemangat untuk menindak lanjuti hasil pelatihan. Peserta mendapatkan wawasan yang baru dalam meragamkan aneka 
kudapan sehat yang berasal dari hasil pertanian warga. Dari LPKK di desa Pajangan bersemangat dengan adanya kerjasama LP3M UST. Kegiatan PKM ini juga dimuat pada surat kabar Minggu pagi pada bulan September 2019.

\section{Saran}

Berdasarkan pelatihan peningkatan lifeskill pembuatan brownies bekatul ibuibu LPKK di Dusun Pajangan, Minggiran Sendangtirto Berbah Sleman baru sebatas pemberian pelatihan pembuatan brownies bekatul, untuk tahap berikutnya perlu diberikan pendampingan untuk teknik pemasaran agar brownies bekatul bisa dijadikan sebagai Usaha Kecil Menengah (UKM) ibu-ibu LPKK di Dusun Pajangan, Minggiran Sendangtirto Berbah Sleman dan bisa diminati oleh konsumen.

\section{Ucapan Terima Kasih}

Kami mengucapkan banyak Terimakasih kepada 1) LP3M UST Yogyakarta, 2) Ketua LPKK Desa Pajangan Minggiran Sendangtirto Berbah Sleman, 3) Prodi PVKK UST Yogyakarta.

\section{DAFTAR PUSTAKA}

[1] A. Huraerah, Pengorganisasian \& Pengembangan Masyarakat Model \& Strategi Pembangunan Berbasis Kerakyatan. Bandung: Humaniora, 2011. [2] E. Suharto, Membangun Masyarakat Memberdayakan Rakyat.
Bandung: RetikeAditama.

[3] Nursalin Y, Bekatul Pangan Yang Menyehatkan. Jakarta: Angromedia., 2007.

[4] F. Sari, R. A. Nugrahani, S. Susanty, and ..., "PELATIHAN PEMANFAATAN DEDAK PADI (RICE BRAN) SEBAGAI BAHAN TAMBAHAN PANGAN DAN PRODUK PERAWATAN TUBUH BAGI MASYARAKAT," Pros. Semin. ..., 2019.

[5] I. W. Retno Widyowati, Wiwied Ekasari, Neny Purwitasari, Aty Widyawaruyanti, Sukardiman Sukardiman, "PELATIHAN PEMBUATAN ES KRIM HERBAL DAN INOVASI KEMASAN PRODUK JAMU DI DUSUN KIRINGAN-JETIS, BANTUL, YOGYAKARTA," $J$. Pemberdayaan Publikasi Has. Pengabdi. Kpd. Masyarakat., vol. 4, no. 1, pp. 1-4, 2020, doi:

https://doi.org/10.12928/jp.v4i1.1200.

[6] Astawan M. dan A. Leomitro, Khasiat Whole Grain: Makanan Kaya Serat untuk Hidup Sehat. Jakarta: Gramedia Pustaka Utama., 2009.

[7] A. E. F. Made Astawan, "Potensi Dedak dan Bekatul Beras Sebagai Ingredient Pangan dan Produk Pangan Fungsiona," J. Pangan, vol. 19, 2010, doi: 10.33964/jp.v19i1.104. 